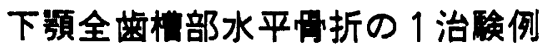

\author{
巨山保・野代忠宏・緋田純一 \\ 空閑祥浩
}

\section{Horizontal fracture of alveolar bone between lower right first molar and left second molar: report of a case}

\author{
Tamotsu Kyoyama - Tadahiro NodaI - Junichi Aketa \\ Yoshihiro KugA
}

\begin{abstract}
Although the fracture of an alveolar bone occurs most frequently singly or in ccmbination with other fractures of the maxilla and mandible, we experienced a rare case of the mandible alveolar bone fracture.

A 45-year-old man was admitted to the hospital because of the low lip injury and limitation of jaw motion.

Examination showed that the oral cavity was detached from the mandible body and the low alveolar bone from the right first molar to left second molar had a horizontal fracture.

The alveolar segment was fixed by circumferential wiring of the mandible and intact teeth in the line of the alveolar bone fracture have been maintained.
\end{abstract}

Key words: Horizontal fracture of alveolar bone

緒

害

雨槽骨骨折については，成書や多くの䫑骨骨折の臨床 統計的観察のなかに記载されている1ー17)。これらの記載 より，歯槽骨骨折は，歯槽骨のみの骨折あるいは颚骨体 骨折と併発している。しかし，いずれにしても，その骨 折範囲は，外力の直接作用した籁囲の歯槽骨部の部分的 骨折がそのほとんどのように推察される。

今回われわれは，下頭骨オトガイ部骨体骨折に下箩両 側歯槽骨（右側第 1 大臼相当部より左側第 2 大臼歯相 当部）が一連となって骨折している患者飞遭遇したの で，先人の報告を涉椫したが，本症例のような所見の記 載は伺い得なかったので，まれな症例ではないかと考 え，症状ならびに処置経過などについて報告する．

九州歯科大学口腟外科学教室第 1 講座 （主任：山田長敬教授）

First Department of Oral Surgery, Kyushu Dental College (Chief: Prof. Nagayoshi Yamada)

受付日：昭和59年 9 月 25 日
症例

患者：45歳 男性.

初診：昭和50年 9 月回。.

主 訴: 外傷による顓機能障害.

既往歴・家族歴：特に記载事項なし。

現病歴: 昭和50年 9 月目，某工場にて，荷物運搬中 飞転倒し，顔面を強打した，ただちに，某外科医院を受 診したが，颓骨骨折と猃断され，止血処圈を受けたのみ で，救急車にて本学付属病院に搬送されてきた。

\section{現 症}

全身所見：栄養良好, きわめて頑強な体格で, 顔面, 口腔以外に異常は認められない，また出血時間，血圧， 脈拍, 呼吸数などに異常は認められない。

口腔外所見：下唇およびオトガイ部が，わずかに浮腫 性畽脹し，ところどころに赤紫色の皮下出血斑と下唇に 約 $1 \mathrm{~cm}$ ，オトガイ部に $2 \mathrm{~cm}$ 程度の繾合創がみられる。

口腔内所見：開口は比較的容易であるも, 閉口は不可 能である。口腔内は，下䫇唇煩側歯肉粘膜が，一線とな ってわずかに剥離され，骨面が露出している，その付近 に少量の血餅と出血がみられる。歯槽部は，一連となっ て下額骨体より遊離して，やや右側に変位した異常咬合 


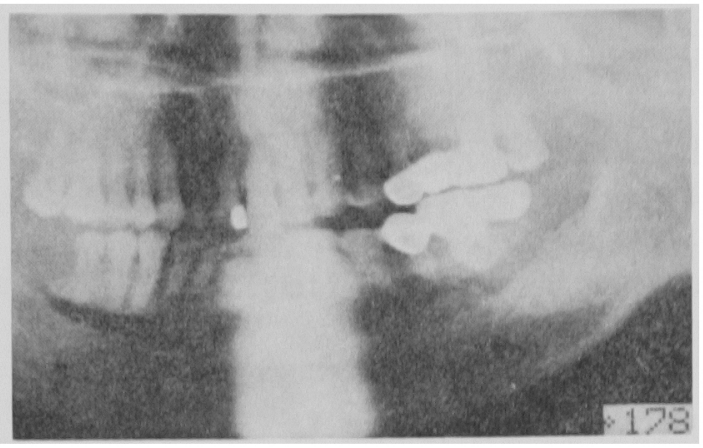

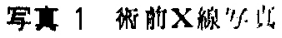

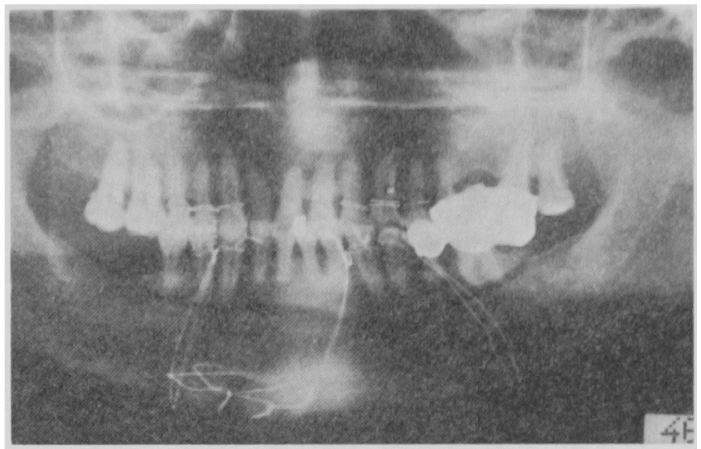

写真 2 術啳10日X線写真

である，触診すると，骨折片は嚾かに左右前後に動嵒す

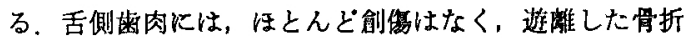
片は舌側幽肉粘膜によって，下顎骨体と連結されてい る. 全掬牙は, 脱臼, 破折などはなく，骨折片内に植立 している。また下䫇骨体を触診すると，オトガイ部は可 動性で骨折が認められた。

X線所見：歯牙を植立した一連の菡博骨骨折片は，下 顠骨骨体より完全に分離浮上し，骨体と骨折片との間に 比較的広い透過性の骨折線が横走している，また，骨体 部に $\sqrt{3}$ 相当部より，やや斜め遠心の下額骨下縁に至る 透過性の単純性骨折線が認められる（写声1）。

診 断: 下顎骨オトガイ部ならびに下䫇畨椿部水平骨 折.

処置ならびに経過：ただちに，局所麻酔のるとに整復 固定手術を行った。まず，下顎骨オトガイ部下緣に，通 法のごとく皮虔切開を加え，骨折部を簬出した。露出し た両骨折端を，互いに接触整復して骨程合を行い，制離 された各軟組織を縫合して，下嚬骨オトガイ部骨折の整 復を行った。ついで，口堅内の変位した齿槽骨骨折片を 下顎骨のほぼ元の位置に戻し, 煩側闲肉の裂創部のと ころどころを仮桻合した。骨折片の固定は，因䌯結禁 (circumferential wiring) で行った。すなわら，誘導針 (腰椎穿刺針) を下顎骨下縁の外皮より刺入して，下顠

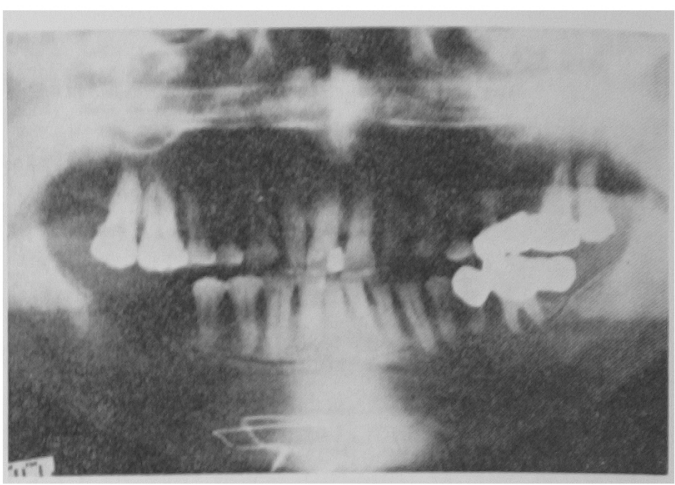

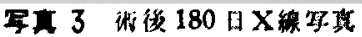

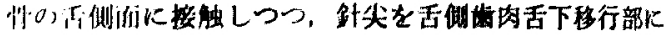

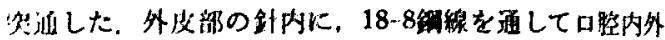

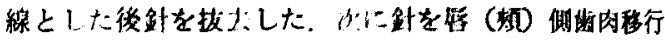

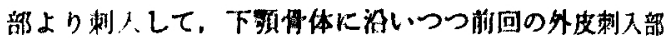

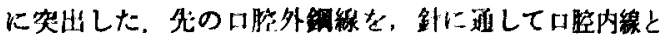

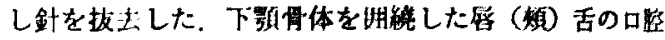

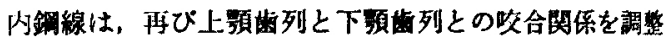

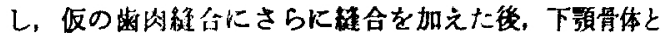

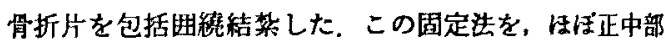
および両倒小四部の 3 か所に実施した。ささらに，固定 を褀強するために，18-8銅線にて，両渭上下額小曰畨部

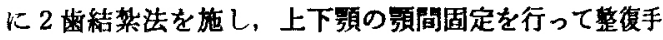
術を䅂了した，術後は 1 邀間抗生詴を投与し，その後は 特に口腔㳙掃に留意した。

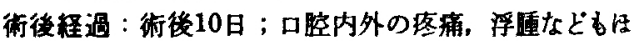

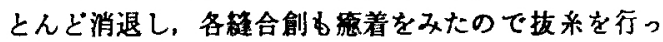

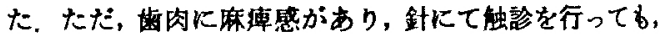
全く感覚の消失している部分も認められた，X線所見 は，喊体骨折部は骨程合により整復され，骨折線は強度 な透過像で判然としている，齿槽骨骨折片は，囲繞結禁 により下影骬体の元の位直に整復されて，注正常な下 顠骨の形態を形成している。しかし，骨折片端の両歯槽 頂部は，わずかに浮上したように下䝷骨と階段状であ る、骨折線は， $\overline{6+7}$ に至る透過性の横一線で， $\overline{21 \mid 1 〜 4}$ の根尖は骨折片内に， $\overline{543 \mid 56}$ は骨折線内に翟められる

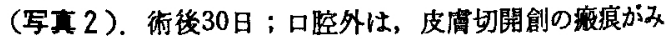
られるのみで，他に異常は珰められない，㤏内は，創

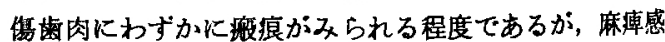
はいまたに残存している．X線所見は，粀博骨折線拧 よび骨体骨折線は明膫であるが，蒾槽骨骨折線内にみら れた $\overline{516}$ の根尖部付近はやや不透過像が増し, 骨の新生 がらかがわれる、音た，階段状であった骨折片端の両歯 槽頂部ははとんど平滑になり，下箩骨体歯槽頂部と移行 的になっている，当日，䫑間固定を除去し，国繞結紮固 定のみとした，ついで歯髄反応について検索を行った。 全雷牙とも陰性であった。 術後60日；開口度3Q.F.B.で 


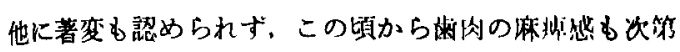

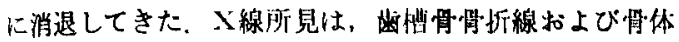
骨折線は明睹であるも30日の所見に比恔して，䏴折線の 不透過性が增し，骨性治涂の進行が認められた。したが

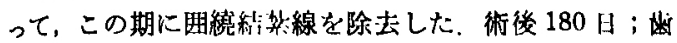

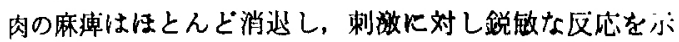

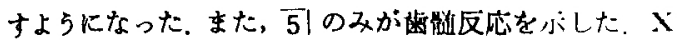
線所見は，歯槽骨骨所線は，大部分判然としているも， $\overline{65}$ 部の骨折線はやや不明睹となってきた。少体北打線

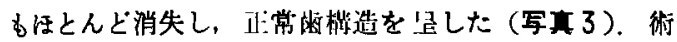

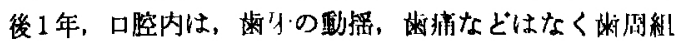

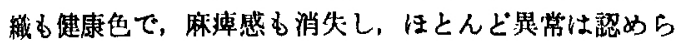

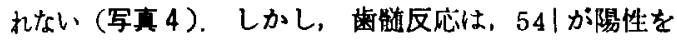
示したが，他の楼牙の崡骮反応は陰性であった，X楾所 見は，骨折線は不透调度が強度となり、ことに左側日西 部においてては，骨改造により正常骨骨構造を呈した（写 真 5).

\section{総括および考按}

歯槽骨骨折は，冒頭で記述したごとく，歯慒骨のみの 骨折と䅡骨骨体骨折と併発した症例がある，まず諸家の 統計的観察のなかから上下顎の歯槽部のみの発生频度に いてみるに, 宮川 $5^{1)}$, 平川 $5^{3)}$, 吉岡 $5^{4)}$, 藤岡 $5^{8)}$,

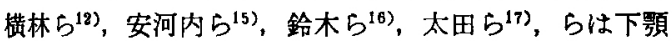
歯槽部に比較して上顎歯楷部に多発し，発生部位に関し $\tau は$, 宮川 $5^{1)}$, Bereny $y^{6)}$, 藤岡 $5^{8)}$, 安河内 $5^{(5)}$, 鈴木 $5^{(6)}$ ，太田 ${ }^{17)}$ の観察では，前崡部が高度の発生率を示 している，宮川ら"は，その理由として，上䝷前歯列は 实出して，下影前料列を被覆している解剖学的特性から であるらと述べている。しかし，下額に多発している文 嗝10)に接する。次に，顠骨骨体骨折を伴亏歯槽骨骨折 に関しては，吉岡 ${ }^{4)}$ ，藤岡 ら ${ }^{8}$ の統計では，上下顎の 差は注同程度の発生率のように判断された，鈴木ら の調査によれば，崡槽部のみの骨折とは相反して，下䫑 画楷部にやや多く発生している，これは，周知のごと く，額骨体骨折は，下顥骨骨折が断然多く，これにつれ て，歯槽骨骨折が併発することから生した結果ではない かと推察した，発生部位に関しては，上下顎骨骨折十齿 榑骨骨折と記載されているものがほとんどで，詳細な発

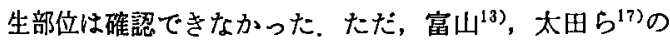
上䫫骨体骨折に対する調查のなかで、これに併発した歯 榑骨骨折は，上下顎とも前崡部に多発していることが同 われた，かよらに，上下顎の米槽骨骨折の発生頻度ある いは発生部位などについて，先人の報告を可及的にその まま引用しまた判読照合してみたが，いずれにしてる 梅槛骨折は，部分的骨折がそのはとんどのようであっ た. 本症例は，下顎骨オトガイ部骨折に併発した

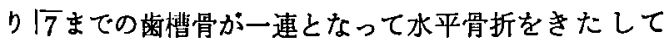

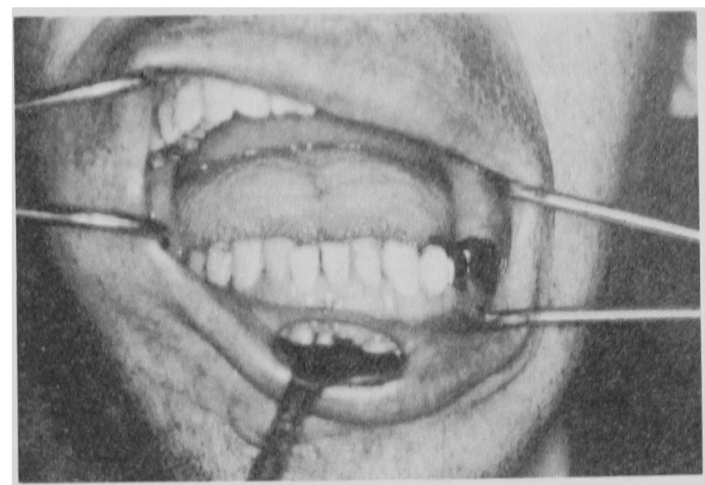

写亲 4 呲後 1 年口腔内写真

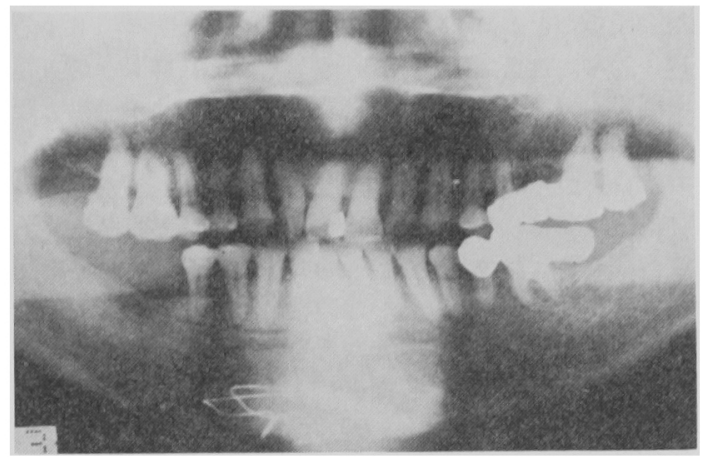

写真 5 徏 1 年X線写真

いた，崡檕骨骨折においては，きわめてまれな症例では ないかと思われた。

菡槽骨骨折における外力の作用機序について，直達拈 よび介達別の外力の作用についての記載はほとんどみら れなかった。たた，野間ら ${ }^{111} ， 川 1$ 村ら 察知見から骨体骨折と崡槽骨骨折の併発症例扎よび隶㡟 骨単独骨折のなかで，介達骨折之想像される症例が 1 2 例あり，他は直達骨折であったと記載されているのが みられた。一方，下顎骨骨折発生機序に関する研究て， 岡 ${ }^{18)}$, 金田 ${ }^{10)}$, Huelke $^{20)}$, 夫馬 ${ }^{21)}$ らは, 下䫑骨オトガイ

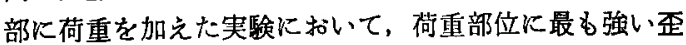
值を生じるが，顎関節部および下顎角部にる著しい歪を 認め，骨折の好発部位を示㗪している，そのなかで， 埇 ${ }^{18)}$ は，オトカイ部の荷重に際して，下顎骨下縁部に比

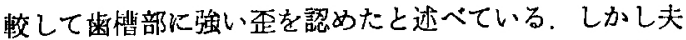

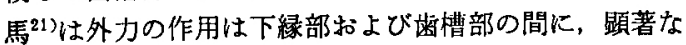
差は認めがたかったと記载し，実験方法の相違から生じ た結果であろらとしている、ここで，本症例の下簤骨オ トガイ部骨折と $\overline{6+7}$ の水平歯槽骨骨折の外力の作用方 向について検討を行ってみた。 まず，オトガイ部骨折 は，患者が転倒した際に該部を倒打したことにより，外 カが直達骨折を生じせしめたことは臨床所見から容易に 


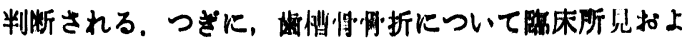

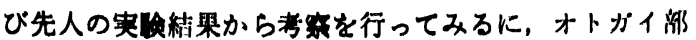

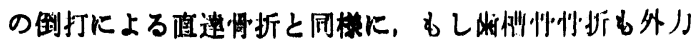

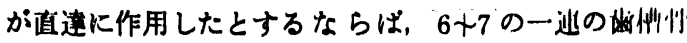
恰折は，前部を中心に多数の小那片に分凯しているの

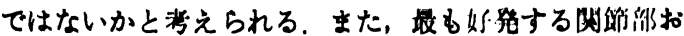
よび下䫘角部などが，伤曾をま奴れていることからし

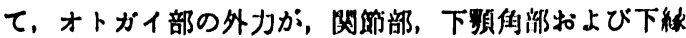
部に作用することなく，オトガイ部に虽力なダィージを

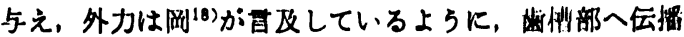
し，介逢佣折を茶起したすのではないかと推案された。

用折線に成速した牙の処贯について，従来，男折線

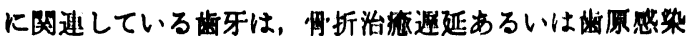
などの合併症を招くおそれがあるとして，些復㽧定勭に 抜去することが，一般的に採用されてきた22 28)，しかる

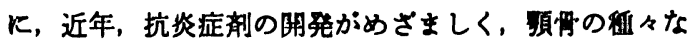
る感染症の治療あるい忬防に大きく貣嗝することとな った。 また，すぐれた口腔清摛器具や菓品の産出によ ク，口腔からの污染予防が容易となった．したがって， 骨折線に関連した崡牙の処置においても，整復時に技去 すべきとされた概念がみなおされ，現在では，橉杪朖漏 による高度な動播齿あるいは整復に障宫をきたす齿牙，

また，保存不可能なら䖵齿などを除いては，抗资症詴投 与や口腔からの污染防止などによる万全の感染防止を行 らことにより，可及的に齿牙の保存につとめ，咀婙機能

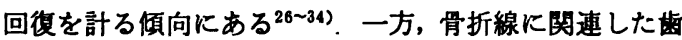
牙の保存後の歯䯣反応について，小野寺 ${ }^{30}$ 忙 8 例中 4 例, Herforth ${ }^{36)}$ は，42\%の陽性率を示したと報告してい ろ. Kahnberg and Ridell ${ }^{35)}$ は，下影骨骨折の骨折線 内あるいは近接している歯牙について $1 〜 3$ 年にわたり 観察した結果，59\%の歯牙は，臨床的，レントゲン的に 完全に回復したと述べている，さらに，齿牙支持組䎧の 骨折線の走行を 6 型に分類し，その骨折線内の菌牙の菡 髄反応の調査によれば，23\%の歯牙は，最初電気刺放に 対する反応は陰性であったが，再娭査の際には陽性反応 を示したと報告している，また，鉡田 ${ }^{33}$ は，骨折線を 5 型に分類し，その線上臨床所見と動物実匼の結果か ら，線上歯牙保存後の蔽髄は，一時的に変化するが，壊 死することなく，時日の経過とともに，正常像に回復す る傾向を示し，骨折型によって異なるか，最高78.3\%の 歯髄反応陽性率をみたと述へてている，な挆骨折線内の歯 嗔反応とはいささか趣を異にするが，田嶋 ${ }^{377}$ は，上䫑骨 の骨切り手術後に関連歯牙の歯随反応は，各歯牙により 違いはあったが，受傷後平均12か月には，82\%の歯牙に 陽性率を示したと述べ, 各㮀牙の陽性率の時期の相遼は, 直接損傷をまぬがれた神経線維からの terminal sprouting 現象が考えられ, 神経損傷の程度あるいは血行障害 の度合により生したるのであろらと推定している，Kent $5^{38)}$ \& alveolar osteotomy 後の歯牙の生活力は, $3 \sim 6$

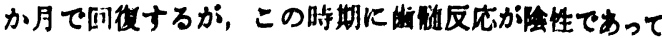
む，術後12〜18か月で回復したと報告している。しかし， 外科的矨㸪乎烆飞際して, small dentalveolar segment

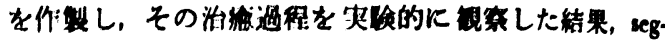

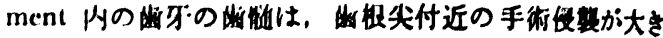
くなれは、，血行们復に失敗し，粗の生活力保持化不利

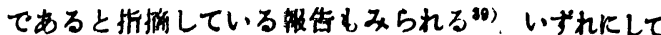

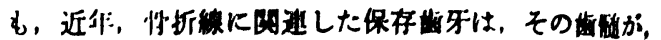

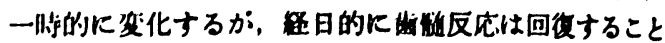

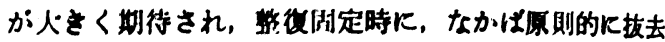

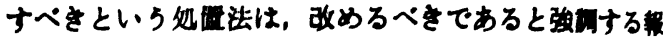

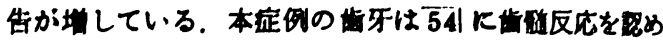

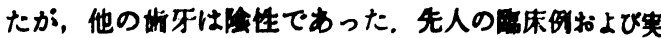

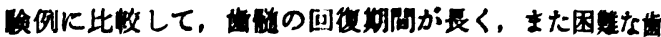

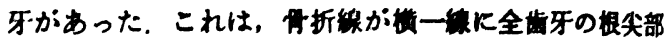

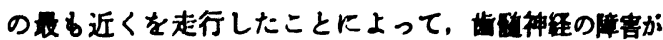
胎度であったからであろらと考えられた。しかるに可

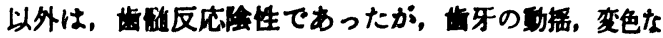

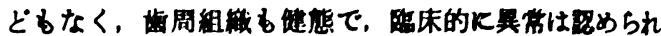
ず，十分咬合機能を果している，骨折镍に闻這した保存

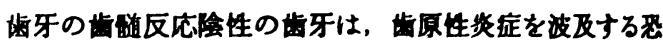

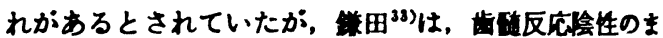
ま保存した齿牙で，3 年経過後る大多数の㡀牙は，変色， 功播などの異常は認められなかったとし，自己の就索を

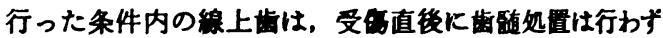

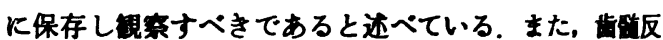

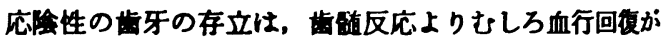
第一で，ことに齿周組䌖の知党回復を重要視している報 告るみられる

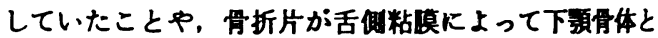
速結か保たれたこと，また，抗资症靔の投与，咚から

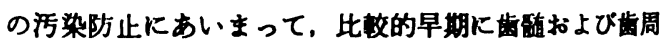
組䋨が回復し，牙の機能を果しているのではないかと 推察した.

歯槽骨骨折の処置について，情骨骨折の処置は，骨 折時に歯牙破折，齿情骨の粉碎による齿牙の脱曰などK よって，保存不可能な齿牙は拔齿，そして齿慒整形が行 われるか，保存可能な歯牙あるいは齿槽骨折片の固定が 可能な症例においては，額骨骨体骨折と同様に，形態的， 機能的回復を目的とした整復, 固定法が採用される。 そ れは，一般に線結禁法や床副子などを応用した固定法で ある，本症例の場合は，固定源となる齿牙が一連となっ て，完全に下領骨体から遊崔し，一見，総義歯のよらな 骨折片の梯相を呈した。整復後の固定には，従来の歯槽 骨骨折の固定では当を得ないので，下額骨囲暁固定法を 選んだ.

囲繞結禁法は，成書にもその術式が詳しく記载されて おり，また本邦においても応用例が散見される ${ }^{10-43)}$ 本 法は, 固定不十分な無影骨折の汪か小児下額骨骨折な 
どに義崡あるいは床副子を利用して，容易にかつ強固な 固定が可能であるとされている，たた本法を応用するに は，術後ある期間，結森線が煩舌稳肉行部上り路出し ているので,これから感染源にならないよ5留善すべき であるとされている．著者らは，本法を応用し，術後，

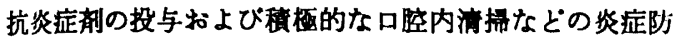
止を努めることにより，伊発症を聕起することなく，形 態的，機能的回復の目的を䔔し本症例に有用な处㯰法で あった。

\section{結}

\section{in}

今回，下額骨オトガイ部を倒打し，䀶部の直寈骨折を 生し，さらに外力が下額齿槽部に伝播して，下額齿槛骨 が，一連（6+7）となって骨折したと思われるめずらし い症例に逼遇した，処圈として，囲結禁固定法にて， 形態的, 機能的回復を計り，本法がかような症例に有用 な術式であることを実証した。 なお，骨折片に植立した 齿牙は，十分な咀哷機能を果している。

\section{引用 文 献}

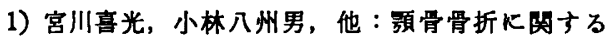
郜床的統訐锶察。口病誌 24:389-398 1957.

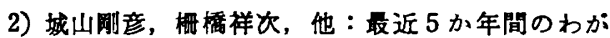

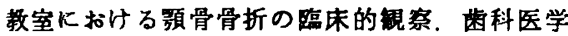
21: 687-697 1958.

3）平川正輝，池尻茂，他：我が教室における嫆 骨骨折患者群についての茺計的兒察。歯界展望 16: 910-915 1959.

4）吉岡敏雄, 岡 光夫, 他：新渴大学齿科におけ る影骨骨体骨折拈よび齿槽骨骨折の 4 年11か月 間にわたる臨床的舅察。口科誌 10: 361-368 1961.

5）前田栄一，安康三男，他：最近 8 か年間に経䀫 した额骨骨折症例についての䠛床梳計的钼察. 口外誌 10: 274-278 1964.

6) Bereny, B.: Unfalkieferchirurgie in Kindesalter. Detsch Stomat 15: 290-299 1965.

7) 福井勝男，中田実，他：昭和34年度以降に捾 ける愹骨骨折の梳計的観察. 日只外誌 13: 2032081967.

8）藤岡幸雄, 中山栄雄, 他 : 過去 3 年間における 影骨骨折患者の動向について. 口科誌 18: 2762841969.

9）古屋英媇，金井羏夫，他：最近13年間における 本学院を訪れた額骨骨折患者群の珫計的観察.

日口外諘 16: 18-24 1970.

10）久野克生，笠原勝彦，他：過去10年間の筫骨骨 折ならびに歯槽骨骨折患者の臨床的䧽察. 日口 外誌 17: 512-515 1971.

11）野間弘康, 河内 博, 他 : 穎㕹面面骨折の珫計

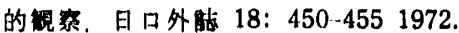

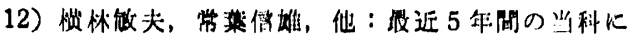

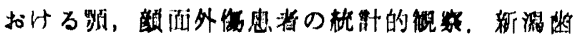
会敦 3：72-77 1973.

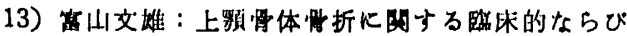
にX線学的研究。口病㩆 42：288-323 1975.

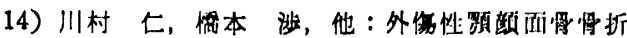

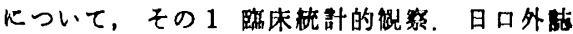
23: 809-818, 1977.

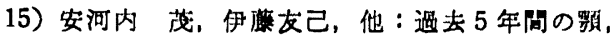

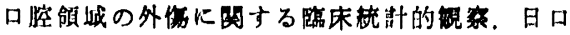
外路 23: 825-829 1977.

16）軨木和茺，三宅久实男，他：遇去 12 年間当教室

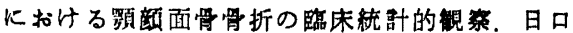
外誌 24：1084-1090 1978.

17）太田 舞, 田岛定夫, 他 : Le Fort 型 Osteotomy 自臨例の檢討。日口外誌 25：132-144 1979.

18）岡達：静的および動的荷重による人下䫛骨 表面の丕について，只科誌 6：74-92 1957.

19）金田敏郎：光弹性実臨による下颚骨の力学的研 究。口病誌 26：2029-2056 1959.

20) Huelke, D.F. and Patrick, L.M.: Mechanics in production of mandibular fractures. Straingauge measurement of impacts to the chin. J dent Res 43: 437-446 1964.

21）夫馬嘉昭：顎面骨骨折に関する力学的研究，歯 科学報 72: 534-604 1972.

22) Clack, H.B.: Practical Oral Surgery. 2nd Ed, Philadelphia, Lea \& Febiger, 1959, p 345.

23) Tnoma, K.H.: Oral Surgery 5 th Ed, Mosby Co, St Louis, 1969, p 618.

24) Bradley, R.L.: Treatment of fractured mandibule. Amer Surg 31: 289 Apil 1965.

25）上野 正：口腔外科領域，顔面外傷の臨床。中 外医学社, 東京, 1968, 205-296頁.

26) Wilkie, C.A., Diecidue, A.A., et al.. Management of teeth in the line of mandibular fracture. J Oral Surg 11: 227-230 1953.

27) Schneider, S. and Stern, M.: Teeth in the line of mandibular fractures. J Oral Surg 29: $107-$ 1091971.

28) Archer, W.H.: Oral and Maxillofacial Surgery 2. 5th Ed, W B Saunders Co, Philadelphia \& London, 1975, p 1069-1073.

29）小浜源郁，吉田 熟，他：下頻骨骨折 317 症例 に関する臨床的検討，特に骨折線上の茵牙につ いて。 日口外誌 23: 237-242 1977.

30）小野寺 満, 高丸宏, 他：歯牙を保存した小 児歯槽骨骨折症例の臨症的微察， みちのく菌学 誌 10: 521979 .

31）境野伸一, 井上温雄, 他 : 影骨骨折の臨床統計 的観察. みちのく茵学誌 10: 53-54 1979.

32）塩田覚，角野博俊，他：額骨骨折線上にある 茵牙の処置とその検討。金医大誌 4：150-161 1979. 


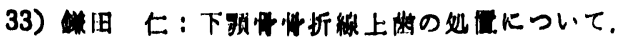
日口外流 29: 1718-1729 1983.

34) Krömer, H.: Teeth in the line of fracture, $A$ conception of the problem besed on a review of 690 jaw fractures. Brit dent J 95: 43-46 1953.

35) Kahnberg, K.E. and Ridell, A.: Prognosis of teeth involved in the line of mandibular fracture. Int J Oral Surg 8: 163-172 1979.

36) Herforth, A.: Zur Frage der Pulpavitalität nach Frontzahntrauma bei Jugendlichen eine Longitudinol Untersuchung. Dtsch Zahnarztl Z 31: 381976.

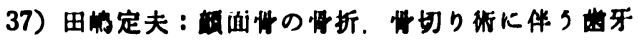

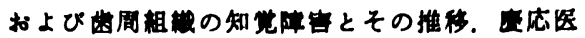
学 52: 279-296 1975.
38) Kent, J.N. and Hind, E.C.: Management of dental facial deformitier by anterior alveolar surgery. J Oral Surg 29: 13-26 1971.

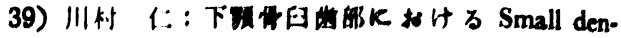

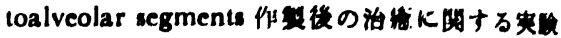
的研苋。日口外就 27: 1736-1755 1981 .

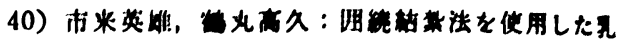

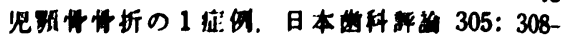
3091968.

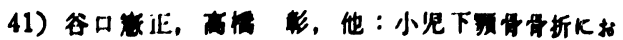

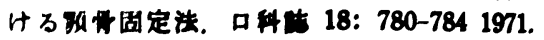

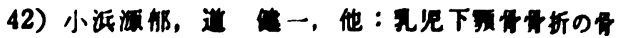

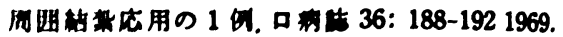

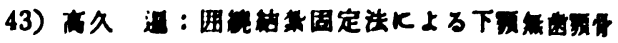

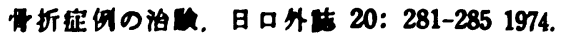

